\title{
JOSÉ BONIFÁCIO, O GEÓLOGO (*).
}

A Sociedade Brasileira de Geologia não poderia deixar de associar-se às justas homenagens que estão sendo prestadas no bi-centenário do nascimento do imortal santistá José Bonifácio de Andrada e Silva.

Graças à gentileza do Grupo Executivo de Trabalho das homenagens a José Bonifácio, brilhantemente presidido pelo Dr. Edgard de Cerqueira Falcão, é-nos dado juntar as nossas modestas mas sinceras homenagens à memória dêsse grande vulto de nossa história.

O nosso comparecimento nestas comemorações impunhase sobremodo, pois êsse ilustre estadista foi o pioneiro das ciências geológicas nas Américas.

Já em 1792 apresentava, à Sociedade de História Natural de Paris, uma Memória sôbre os diamantes do Brasil. Dos seus trabalhos, aquêle realizado em princípios de 1820 , juntamente com seu irmão Martim Francisco, Viagem Mineralógica na Província de São Paulo, é o mais conhecido, encerrando observações precisas sôbre os gnaisses, granitos e xistos da Serra de Paranapiacaba.

$\mathrm{Na}$ realidade, nunca passou desapercebida aos geólogos brasileiros, a valiosa obra de José Bonifácio. Assim é que deve ser lembrado, que a medalha comemorativa do $2 .^{\circ}$ Congresso Panamericano de Engenharia de Minas e Geologia, realizado em Petrópolis em 1946, trazia a efígie do geólogo José Bonifácio de Andrada e Silva.

Reconhecendo o seu pioneirismo nas ciências geológicas, a Sociedade Brasileira de Geologia decidiu instituir, em 1957, o prêmio José Bonifácio, sob forma de uma medalha de ouro a ser conferida, anualmente, ao geólogo que tenha contribuído substancialmente para o progresso geológico do País. A

$(\bullet)$. - Palavras proferidas pelo Prof. Dr. Setembrino Petri, presidente em exercício da Sociedade Brasileira de Geologia, por ocasião da homenagem dos geólogos paulistas a José Bonifácio de Andrada e Silva, realizada em Santos, no dia 3 de julho de 1963. 
Sociedade vem, desde 1958, cumprindo tal resolução, conferindo, anualmente, medalha de ouro maciço de 18 quilates, pesando cêrca de 7.0 gramas. A entrega realiza-se nos congressos anuais promovidos pela Sociedade.

A referida medalha possui no anverso, a efígie de José Bonifácio e os dizeres Prêmio José Bonifácio de Andrada e Silva e no reverso o nome do premiado e o emblema da Sociedade Brasileira de Geologia, sendo entregue juntamente com um pergaminho.

A comissão julgadora que escolheu os primeiros premiados foi constituída pelos membros da diretoria (gestão de 1958), os quais enviaram circulares aos presidentes dos núcleos regionais, solicitando aprovação dos nomes lembrados ou indicação de outros nomes.

A referida comissão julgou oportuna uma homenagem aos ilustres geólogos: Avelino Inácio de Oliveira, Othon Henry Leonardos e Viktor Leinz, que foram agraciados com as medalhas na ocasião da sua primeira distribuição.

Os Drs. Avelino Inácio de Oliveira e Othon Henry Leonardos notabilizaram-se não só pela pesquisa do solo pátrio bem como pela sua associação na obra magnífica que é a Geologia do Brasil, obra de consulta que ainda continua sendo indispensável a todos aquêles que se dedicam à Geologia nacional. Destacou-se Oliveira como grande geólogo da Amazônia e Leonardos especialmente pelos trabalhos de cunho econômico.

O professor Dr. Viktor Leinz notabilizou-se sob dois aspectos: pesquisador e mestre. Entre seus inúmeros trabalhos destacam-se os que dedicou à glaciação paleozóica do Sul do Brasil, gênese do carvão nacional e vulcanismo basáltico brasileiro.

A entrega dessas medalhas foi feita durante o XII Congresso Brasileiro de Geologia, realizado em Belo Horizonte, nos primeiros dias de setembro de 1958.

Por proposta de um dos membros da Sociedade, Prof. Dr. Reynaldo Ramos Saldanha da Gama, a comissão da medalha José Bonifácio passou a ser constituída pelos elementos prèviamente premiados no ano anterior.

Tal comissão premiou em 1959, o Dr. William D. Johnston Jr. e o Dr. Sylvio Fróes de Abreu. A Sociedade homenageou na pessoa do primeiro, a valiosa contribuição ao desenvolvimento de nossa Geologia realizada pelos geólogos norte-americanos. O Dr. Sylvio Fróes de Abreu destacou-se por trabalhos de grande valor no campo da Geologia Econômica. As duas medalhas 
foram entregues durante o XIII Congresso da Sociedade realizado em São Paulo, em princípios de novembro.

A única medalha conferida em 1960, foi entregue ao Dr. Elysiário Távora em reconhecimento às suas magníficas contribuições para a elucidação das estruturas de diversos minerais por métodos roentgenográficos. A entrega deu-se em Brasília, durante o XIV Congresso Brasileiro de Geologia, em novembro.

Durante o XV Congresso, realizado em Florianópolis, em novembro de 1961, recebeu a medalha o Dr. Luciano Jacques de Morais, geólogo entusiasta, autor de inúmeras publicações, com quase 40 anos de ininterrupta produção científica.

Em novembro de 1962, recebeu o prêmio José Bonifácio, por ocasião do XVI Congresso Brasileiro de Geologia, em Pôrto Alegre, o Dr. Glycon de Paiva, notável geólogo e economista, que iniciou seus trabalhos científicos no já remoto ano de 1927.

A entrega das medalhas, nos Congressos Brasileiros de Geologia, faz reviver anualmente entre nós, a figura imortal do ilustre estadista e geólogo, que tanto honra a cidade em que nasceu.

\section{SETEMBRINO PETRI}

Presidente em exercício da Sociedade Brasileira de Geologia. 